\title{
Fruit and Vegetable Processing Sector in Bengal: Opportunities, Status and Challenges
}

\author{
Sabyasachi Ojha
}

Department of Education, Government Sponsored High School, Government of West Bengal, West Bengal, India

Corresponding author: sabyasachiojha10@gmail.com

\begin{abstract}
Fruit and vegetable processing sector is one of the core segments under food processing in Bengal. Development of this sector is critically important to the expansion and diversification of state's agricultural sector. It provides vital linkages and harnesses synergies between the two pillars of our economy, industry and agriculture. Bengal has huge potentials for the growth of this sector in the state. But such growth potentials are constrained by several factors. The processing of fruit and vegetable is still at a very low level in Bengal (2.8 per cent) as well as in India (2.2 per cent) against the highest post harvest losses (27 per cent). The main constraint lies behind this with infrastructure, technology, quality measurement and lack of farm-firm linkages. In view of the above facts this paper tries to examine the streangths of this particular sector in the state and highlighting on its existing constraints. The paper also made suggestions to achieve the future progress of this sector in Bengal.
\end{abstract}

Keywords: Fruit and vegetable processing, Post harvest losses; Farm-firm linkages; Liberalization; Level of processing; Diversification of agricultural

Bengal is the largest producer of pineapple, and vegetables, and the second largest producer of potato and litchi, and the significant producer of mango, mandarin orange and sapota in the country. Advantages of six agro-climate zones, fertile soil and proper irrigation facilities make it possible for Bengal to maintain such strong production base in fruit and vegetable. There are six declared 'Agri Export Zones' (AEZ) in the state. Twelve Food Parks and one Mega Food Park at Jangipur are being operated in the state. The state is the hub of economic activities in the entire eastern and north eastern India. With good logistic support, the state is well connected both nationally and internationally. Availability of large pool of educated farm labour and technical manpower at comparative rates in the state is favourable for future growth of labour intensive fruit and vegetable processing sector in Bengal.

Development of fruit and vegetable processing is critically important to the expansion and diversification of the agricultural sector in India as well as Bengal. Such activities would reduce seasonality of consumption of a range of processed food, minimize post-harvest losses, and increase profitability and sustainability of production systems besides their impact on increasing farm income, rural employment and foreign exchange earnings and reduction in marketing risks (Roy and Ojha, 2012). It also provides vital linkages and harnesses synergies between the two pillars of our economy, industry and agriculture.

The environment for 'food processing' in general and 'fruit and vegetable processing' in particular both at national level as well as at the state level has changed significantly after liberalization, specifically after 2000's. A series of policy measures has been taken in favour of this sector. The fruit and vegetable processing have been accorded the status of 'Sunrise Industry' in the country with a number of special relief and incentives (Roy, 2010). Further this sector has been identified as 'Priority Sector' for bank lending. 
Despite several incentives and advantages, the processing of fruit and vegetable is still at a very low level in Bengal (2.8 per cent) as well as in India (2.2 per cent) against the highest post harvest losses (27 per cent) of this particular sector. Many of the developed and developing countries have shown much better performance in processing fruit and vegetable. Even within India, relative performance of various states and regions like Delhi, Maharashtra, Chandigarh, Goa, Haryana, Rajasthan, etc. are much better than Bengal in this respect.

The questions that arise then: what have been the major constraints to the proper exploration of such a huge potential for the sector in the state? What kind of institutional arrangements, technological interventions and policy supports are needed to overcome such threats of this sector?

With this background this paper aims to (i) examine the present status of this sector in the state and opportunities that prevails for the growth of this sector, (ii) identify the constraints/drivers to the development of fruit and vegetable processing in Bengal and (iii) policy supports that are needed to overcome such threats of this sector?

\section{AREA AND PRODUCTION}

The finding of the study reveals that the performance of Bengal both in case of production and processing of fruit and vegetable is commendable. A steady growth both in production as well as processing of fruit and vegetable has been achieved by the state since liberalization, particularly in post 2000's. A remarkable increase becomes evident in the trends in production of fruit in the state during post liberalization period. While total production of fruit in Bengal was merely 1131.7 thousand metric tons in 1991-92, it has nearly tripled to 2860.9 thousand metric tons in 2009-10 (Table 1). Even, the state has been performing better in case of fruit production compared to national level. Production of fruit in Bengal has been growing at the compound rate of 5.2 per cent between the periods 1991-92 to 2009-10 while such growth rate at national level is observed at 4.1 per cent only. In case of vegetables also, state's performance is inspiring. A more or less similar picture emerges in the sense that the compound growth rate in vegetable production (4.58 per cent) in Bengal exceeds that in case of India (4.53 per cent) (Table 2).

In productivity of fruit, the annual compound growth in Bengal is observed at 1.34 per cent compared to a very poor growth profile at the national level of -0.26 per cent over the period in reference. However, such performance in case of vegetables is found to be relatively at much lower levels compared to the all India picture. Even if, annual compound growth rate of productivity of vegetable is positive in Bengal (at 1.0 per cent), it is much below than that at the national level of 1.9 per cent. Productivity differentials in case of vegetable

Table 1: Area, production and yield of fruit in Bengal vis-à-vis in India (Area in 000' hectares and Production in 000' Metric Tons)

\begin{tabular}{|c|c|c|c|c|c|c|c|c|c|}
\hline Years & $\begin{array}{c}\text { Area in } \\
\text { W.B. }\end{array}$ & $\begin{array}{l}\text { Area in } \\
\text { India }\end{array}$ & $\begin{array}{c}\text { Share } \\
(\%)\end{array}$ & $\begin{array}{l}\text { Production in } \\
\text { W.B. }\end{array}$ & $\begin{array}{l}\text { Production in } \\
\text { India }\end{array}$ & $\begin{array}{l}\text { Share } \\
(\%)\end{array}$ & $\begin{array}{l}\text { Yield MT/ } \\
\text { Ha (WB) }\end{array}$ & $\begin{array}{c}\text { Yield } \\
\text { MT/Ha (India) }\end{array}$ & $\begin{array}{c}\text { Yield } \\
\text { difference }\end{array}$ \\
\hline 1991-92 & 111.3 & 2874.0 & 3.9 & 1131.7 & 28632.0 & 4.0 & 10.2 & 10.0 & 0.2 \\
\hline 2002-03 & 152.2 & 3788.0 & 4.0 & 1785.6 & 45203.0 & 4.0 & 11.7 & 11.9 & -0.2 \\
\hline 2003-04 & 160.9 & 4675.0 & 3.4 & 2016.1 & 45645.0 & 4.4 & 12.5 & 9.8 & 2.8 \\
\hline 2006-07 & 187.1 & 5553.7 & 3.4 & 2640.5 & 59563.3 & 4.4 & 14.1 & 10.7 & 3.4 \\
\hline 2007-08 & 194.3 & 5857.2 & 3.3 & 2766.7 & 65586.8 & 4.2 & 14.2 & 11.2 & 3.0 \\
\hline 2008-09 & 203.2 & 6101.2 & 3.3 & 2775.6 & 68465.6 & 4.1 & 13.7 & 11.2 & 2.4 \\
\hline $2009-10$ & 208.3 & 6329.2 & 3.3 & 2860.9 & 71515.5 & 4.0 & 13.7 & 11.3 & 2.4 \\
\hline
\end{tabular}

Data Source: DFPI \& H, GoWB and NHB. 
Table 2: Area, production and yield of vegetables in Bengal vis-à-vis in India (Area in 000' hectares and Production in $000^{\prime}$ Metric Tons)

\begin{tabular}{cccccccccc}
\hline \multirow{2}{*}{ Years } & $\begin{array}{c}\text { Area in } \\
\text { W.B. }\end{array}$ & $\begin{array}{c}\text { Area in } \\
\text { India }\end{array}$ & $\begin{array}{c}\text { Share } \\
\mathbf{( \% )}\end{array}$ & $\begin{array}{c}\text { Production in } \\
\text { W.B. }\end{array}$ & $\begin{array}{c}\text { Production } \\
\text { in India }\end{array}$ & $\begin{array}{c}\text { Share } \\
\mathbf{( \% )}\end{array}$ & $\begin{array}{c}\text { Yield MT/Ha } \\
\text { (WB) }\end{array}$ & $\begin{array}{c}\text { Yield } \\
\text { MT/Ha (India) }\end{array}$ & $\begin{array}{c}\text { Yield } \\
\text { difference }\end{array}$ \\
\hline $1991-92$ & 456.0 & 5593.0 & 8.2 & 4680.0 & 58532.0 & 8.0 & 10.3 & 10.5 & -0.2 \\
$2000-01$ & 838.8 & 6250.0 & 13.4 & 10130.2 & 93849.0 & 10.8 & 12.1 & 15.0 & -2.9 \\
$2001-02$ & 874.9 & 6156.0 & 14.2 & 10253.0 & 88622.0 & 11.6 & 11.7 & 14.4 & -2.7 \\
$2002-03$ & 827.8 & 6092.0 & 13.6 & 10636.0 & 84815.0 & 12.5 & 12.8 & 13.9 & -1.1 \\
$2003-04$ & 859.9 & 6309.0 & 13.6 & 10918.9 & 93165.0 & 11.7 & 12.7 & 14.8 & -2.1 \\
$2003-04$ & 868.4 & 6744.0 & 12.9 & 10996.6 & 101246.0 & 10.9 & 12.7 & 15.0 & -2.3 \\
$2005-06$ & 889.8 & 7164.0 & 12.4 & 11556.7 & 109049.5 & 10.6 & 13.0 & 15.2 & -2.2 \\
$2006-07$ & 903.6 & 7580.5 & 11.9 & 12088.0 & 114993.3 & 10.5 & 13.4 & 15.2 & -1.8 \\
$2007-08$ & 912.4 & 7848.3 & 11.6 & 12556.0 & 128448.8 & 9.8 & 13.8 & 16.4 & -2.6 \\
$2008-09$ & 922.8 & 7980.7 & 11.6 & 12803.5 & 129076.8 & 9.9 & 13.9 & 16.2 & -2.3 \\
$2009-10$ & 932.7 & 7984.8 & 11.7 & 13026.5 & 133737.6 & 9.7 & 14.0 & 16.7 & -2.8 \\
\hline Average & $\mathbf{7 8 4 . 5}$ & $\mathbf{6 2 6 0 . 9}$ & $\mathbf{1 2 . 6}$ & $\mathbf{9 8 0 4 . 3}$ & $\mathbf{9 0 6 6 8 . 5}$ & $\mathbf{1 1 . 0}$ & $\mathbf{1 2 . 4}$ & $\mathbf{1 4 . 2}$ & $\mathbf{- 1 . 8}$ \\
\hline C.A.G.R. & $\mathbf{3 . 2}$ & $\mathbf{2 . 7}$ & $\mathbf{0 . 4}$ & $\mathbf{4 . 5}$ & $\mathbf{4 . 5}$ & $\mathbf{- 0 . 1}$ & $\mathbf{1 . 3}$ & $\mathbf{1 . 9}$ & \\
\hline
\end{tabular}

Data Source: DFPI \& H, GoWB and NHB.

remain negative in Bengal compared to national level, after liberalization (1991).

And, it is clear from the above picture that Bengal has strong production base both in case of fruit and vegetables production. Banana occupies the highest share following mango, pineapple, papaya, and jack fruit in total production of fruit in the state. Moreover, banana, papaya, guava, jack fruit, and litchi are the top five items under fruit which have observed higher production growths during the last ten years whereas in case of vegetables such higher growth rates have been observed for onion, tomato, peas, radish, and cucurbits. The district of north 24 parganas is the highest fruit producing district in the state and Nadia, Murshidabad, Jalpaiguri, Darjeeling, Malda, and Hoogly are the major fruit producing districts in Bengal. Murshidabad district produces the maximum amount of vegetables in the state and Nadia, Cooch Behar, North 24 parganas, South 24 parganas, and Bankura are the major vegetable producing districts. This clearly points out that the state has huge raw material base for processing a variety of processed food items.

\section{PROCESSING}

One of the main findings of our research work is that at present 2.78 per cent of total fresh fruit and vegetable are processed in Bengal which is higher than that of national level of processing (2.2 per cent). The combined growth rate for fruit and vegetable production is estimated at 4.6 per cent in Bengal while it is remarkable and encouraging to see that the growth rate in processed fruit and vegetable production in the state is observed three times more i.e. 14.0 per cent during 1991 to 2009. In absolute terms, the processed fruit and vegetable production jumped from a mere 33.7 thousand metric tons to 444.1 thousand metric tons between the same reference periods. The relative performance of the state in terms of fruit and vegetable processing has improved significantly during the last 10 years though the present level of processing is only 2.78 per cent.

While at the national level the percentage of fruit and vegetable processing has improved marginally from 2 per cent to 2.2 per cent between 1998 and 2009, in Bengal it has improved remarkably from 0.88 per cent to 2.78 per cent between the same time periods (Table 3). In Bengal, level of processing has increased more than double between last ten years and this is much impressive performance than that achieved at national level at the same time periods. In terms of share in processing vis-a-vis production among the major fruit and vegetables producing states in India, Bengal's position has improved substantially during the last 10 years (Fig. 1).

It has been identified in the study that the state is the significant producer of processed fruit and vegetable 
$\mathcal{P O j h a}$
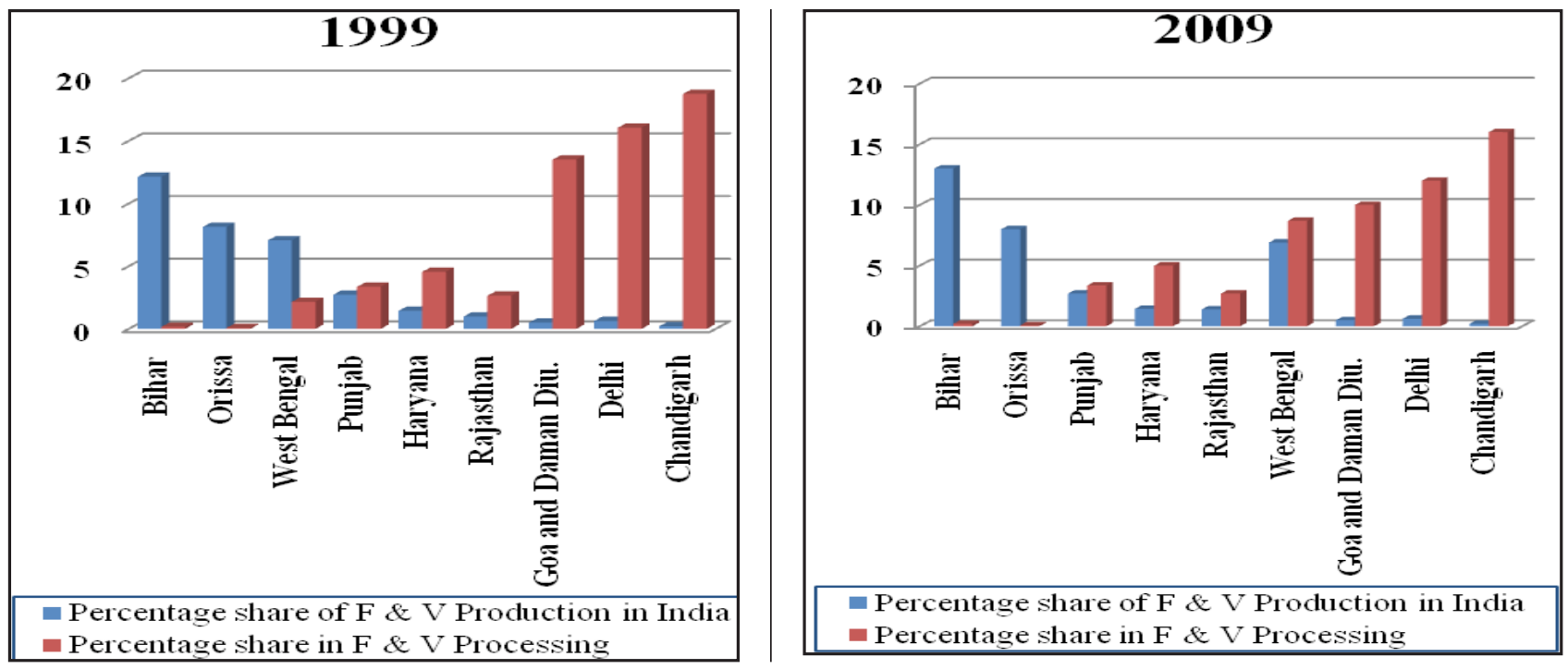

Fig. 1: Relative performance of Bengal in terms of fruit and vegetable processing

Data Source: Various Secondary Sources.

Table 3: Level of fruit and vegetable processing in Bengal (Production in 000' Metric Tons)

\begin{tabular}{cccccc}
\hline Year & $\begin{array}{c}\text { Fruit } \\
\text { production }\end{array}$ & $\begin{array}{c}\text { Vegetables } \\
\text { production }\end{array}$ & $\begin{array}{c}\text { F \& V production } \\
\text { (combined) }\end{array}$ & $\begin{array}{c}\text { Processed } \\
\text { F \& V production }\end{array}$ & $\begin{array}{c}\text { Level of processing } \\
\text { (in \%) out of total F \& V } \\
\text { production }\end{array}$ \\
\hline 1991 & 1131.70 & 4680.00 & 5811.70 & 33.71 & 0.58 \\
2000 & 1657.10 & 10130.20 & 11787.30 & 107.26 & 0.91 \\
2001 & 1985.50 & 10252.96 & 12238.46 & 124.83 & 1.02 \\
2002 & 1785.60 & 10635.95 & 12421.55 & 140.39 & 1.13 \\
2003 & 2016.08 & 10918.85 & 12934.93 & 158.33 & 1.22 \\
2004 & 2128.30 & 10996.62 & 13124.91 & 191.59 & 1.46 \\
2005 & 2301.70 & 11556.74 & 13858.44 & 272.24 & 1.96 \\
2006 & 2640.54 & 12087.96 & 14728.49 & 344.65 & 2.34 \\
2007 & 2766.67 & 12555.96 & 15322.63 & 374.59 & 2.44 \\
2008 & 2775.60 & 12803.46 & 15579.06 & 405.00 & 2.60 \\
2009 & 2860.92 & 13026.53 & 15887.45 & 441.41 & 2.78 \\
CAGR & 5.2 & 4.5 & 4.6 & 14.0 & 9.4 \\
\hline
\end{tabular}

Data Source: DFPI \& H, GoWB; DFEVPI (ER), GoI and NHB (For data before 2002).

items like 'Fruit based ready to serve products', 'Chutney', 'Sauces' (other than tomato), 'Pickles', 'Tomato products', 'Non fruit syrup', 'Fruit pulp' and 'Preserved items'. Again, it is revealed, Bengal is the only producing state of processed items like 'Mango Slice in Brine' (MSIB); 'Candied/ Crystallized Fruit', and 'Dehydrated Vegetable', in the entire eastern part of the country. However, the state itself contributes more than 62 per cent in production of processed fruit and vegetable items produced by the entire eastern part of the country comprising Bihar, Bengal, Orissa, Jharkhand, Andaman, and Nicober
Island. Presently over thirteen thousand licensed food processing industries are operating in the state out of which around 550 are identified as fruit and vegetable processing units. There have been 342 'Fruit Product Order' (FPO) units functioning in the state till 2010. There also has been a noticeable growth in the number of cold storages in the state during the same periods of time.

\section{POLICY SUPPORT}

Several policies have been undertaken over time both at state level as well as at union level towards 
horticultural production and processing. We have examined the impact of such policy changes towards growth and performance of fruit and vegetable processing sector in Bengal. A review has been made on the nature of policy changes towards Indian food processing sector since 1960's and it observed from the review that food processing sector have managed to get attraction to the policy makers in post liberalization periods. During late 90 's, this sector has occupied highest priority to the policy builders. 'The Ministry of Food Processing Industries' (MOFPI) has been established in 1999 in order to promote financial supports and guide to this sector. The fruit and vegetable processing sector has been given the status of 'Sunrise Industry' by Indian government and has been included in the list of priority sector for bank lending in 1999. Establishment of Export Oriented Units (EOU) under food processing sector has got special focus in this period. While commercial production was a part of major policies during 1990's, the main focus was on the industrial sector which occupied the top position in the priority list.

As a result farmers were neglected, even though this period witnessed emphasis on high value crops. Accordingly the food processing sector received a significant weight-age. Policy support for food processing sector could be observed during 2000's. In fact the thrust on 'Food and Nutritional Security' was the major feature of overall strategy in the post liberalization period. A number of hitherto new developments and agendas could be observed in the post liberalization period on account of 'Millennium Development Goals' (MDGs) which was introduced at the policy level. Creation of rural employment was one of the main thrust under MDGs during 2000's. Policies like start of 'National Horticultural Mission' (2005-06; Tenth Five Year Plan) and 'National Rural Livelihood Mission' (2010) gained tremendous importance during 2000's. Moreover contract farming, crop diversification and quality control qualified to be specific interventions during this period.

This paper has focused on the profile of specific policies that have been taken by union government as well as government of Bengal towards fruit and vegetable processing sector in particular since 1990's. Initiatives that have been taken to promote fruit and vegetable processing in the state and incentives and supports provided by the state government towards this sector over time have been highlighted in this study with special care. Moreover, the state government has announced a separate policy for its food processing sector in 2011 in the name of 'The Food Processing Policy 2011'.

\section{POLICT IMPACT}

A positive trend in investment in food processing sector has been observed in the state after 2000. Total investment in food processing in the state which was only ₹ 79 crore in 2000-01 stood up by many folds to ₹ 787.85 crore in 2010 (Fig. 2).

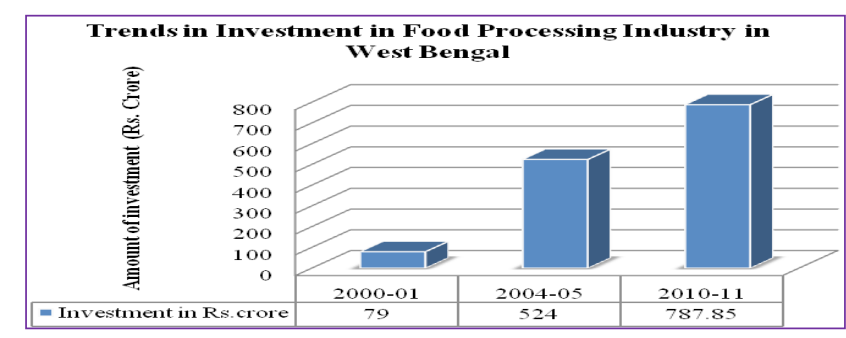

Fig. 2: Trends in investment in food processing in Bengal

Data Source: DFPIE H; GoWB.

Some of the leading corporate houses such as Dabur, Frito-Lay, Venkateshwara Hatcheries and Nestle have initiated projects in the food-processing sector or have started marketing products manufactured in the state. Frito-Lay India has set up a unit for manufacturing potato chips with a projected investment of around ₹ 70 crore at Sankrail Food Park, Howrah and Potato King Pvt. Ltd. has a world-class plant at Howrah for production of potato powder with latest technology and machinery imported from Florigo, Holland and the US. The entire production of the plant is fully automatic and the finished goods are untouched by hand. The company has cold storage facilities near the plant in order to supply raw materials at desired and regulated temperatures when there is no availability of fresh, raw potatoes. The company is currently going for further expansion and setting up another unit.

In 2004, the Dabur Pvt Ltd, another food giant in India, has set up a fruit processing plant at Siliguri at an estimated cost of ₹ 20 crore. Pataka Food Products Pvt Ltd also plans to set up a modern fruit and vegetable processing unit at Jangipur, Murshidabad. The company has already purchased about 50 acres of land and civil construction work 
is about to commence. Keventor Biotech Pvt Ltd signed a MoU with the Department of Food Processing Industries \& Horticulture for setting up a unit for exporting fresh and frozen green vegetables. The unit has already come up near Barasat. Similarly, Elque \& Co. had also signed a MoU with the Department of Food Processing Industries and Horticulture for exporting frozen vegetables. They have set up their unit at North 24-Parganas with an investment of around ₹ 5 crore.

About 6421 new food processing units have been established in Bengal across the districts in the last five years (i.e. from 2007 to 2011), out of which 153 have been launched in fruit and vegetable processing sector (Table 4). As a result of all such initiatives more than 30 thousand employment has been generated in this sector in the state till 2006 and over fifty thousand of employment has been created in food processing sector as a whole during 2007 to 2011, with around fifteen hundred of employment in fruit and vegetable sector alone. Since 2007, a large numbers of new fruit and vegetable processing units have been established in the state particularly in the district of Malda, North and South 24 parganas, Hoogly, Dakshin Dinajpur, and Jalpaiguri. It is noteworthy to mention that per unit employment generation in the state during last five years i.e., from 2007 to 2011, was at a higher rate in fruit and vegetable processing industries (9.4) than food processing industries as a whole (8.03).

\section{CONSTRAINTS}

One of the major objective of this paper is to identify the technological, institutional, socio-economic and policy constraints to the development of fruit and vegetable processing in Bengal. We have identified such constraints both at the point of view of fruit and vegetable cultivators as well as processing firms operating in the state.

From cultivator's end, the most alarming problems are inadequate infrastructure, use of primitive technology in cultivation, lack of storage facilities, and marketing of their products. Poor infrastructure is one of the major constraints to the development of fruit and vegetable cultivation in the state. Under infrastructure, the problem arises mostly on poor transportation, lack of storage facilities, non-availability of electricity, poor production infrastructure, and improper market infrastructure. We have identified through our survey that most of the producing zones are not electrified in the respective districts. Even, storage facilities are

Table 4: Dist-wise newly registered FPI and FVPI with respective new employment in the state from 2007 to 2011

\begin{tabular}{|c|c|c|c|c|c|c|}
\hline Districts & FPI & $\begin{array}{l}\text { Employment in } \\
\text { FPI }\end{array}$ & $\begin{array}{l}\text { Employment / } \\
\text { FPI }\end{array}$ & FVPI & $\begin{array}{l}\text { Employment in } \\
\text { FVPI }\end{array}$ & Employment/FVPI \\
\hline Burdwan & 354 & 4741 & 13.39 & 6 & 57 & 9.5 \\
\hline Birbhum & 200 & 2703 & 13.52 & 1 & 10 & 10.0 \\
\hline Bankura & 302 & 2047 & 6.78 & 1 & 15 & 15.0 \\
\hline Midnapur( E) & 621 & 4934 & 7.95 & 3 & 13 & 4.3 \\
\hline Midnapur (W) & 620 & 3464 & 5.59 & 6 & 54 & 9.0 \\
\hline Howrah & 159 & 1348 & 8.48 & 6 & 88 & 14.7 \\
\hline Hoogly & 356 & 3708 & 10.42 & 15 & 58 & 3.9 \\
\hline 24 Parganas (N) & 454 & 3719 & 8.19 & 25 & 249 & 10.0 \\
\hline 24 Parganas (S) & 265 & 2505 & 9.45 & 14 & 66 & 4.7 \\
\hline Nadia & 319 & 2195 & 6.88 & 8 & 66 & 8.3 \\
\hline Murshidabad & 347 & 2311 & 6.66 & 4 & 43 & 10.8 \\
\hline Uttar Dinajpur & 244 & 2026 & 8.30 & 1 & 5 & 5.0 \\
\hline Dakshin Dinajpur & 341 & 3698 & 10.84 & 12 & 34 & 2.8 \\
\hline Malda & 654 & 4897 & 7.49 & 31 & 356 & 11.5 \\
\hline Jalpaiguri & 488 & 2493 & 5.11 & 10 & 63 & 6.3 \\
\hline Darjeeling & 138 & 1861 & 13.49 & 6 & 184 & 30.7 \\
\hline Coochbihar & 336 & 1620 & 4.82 & 2 & 65 & 32.5 \\
\hline Purulia & 223 & 1291 & 5.79 & 2 & 17 & 8.5 \\
\hline Bengal & 6421 & 51561 & 8.03 & 153 & 1443 & 9.4 \\
\hline
\end{tabular}

Data Source: DFPIE H; GoWB. 
not available in the adjacent of producing areas. Non availability in storage facilities gear up the post harvest losses of the farm produces. Further, transportation is a big problem. Most of the roads connecting to the local market and production areas are identified as lake roads and farmers have to depend on rickshaw van to carry their product in market due to such poor conditions of road. Use of a decade-ago, back-dated, traditional techniques by the farmers in case of both selected crops becomes an acute problem. Even, the farmers fail to avail the modern cultivation techniques and methods due to lack of proper training facilities in the state. Lack of specialized manpower is another problem area in fruit and vegetable cultivation in the state. Farmers have to face an acute problem in marketing their produce. In case of both the crops marketing is done mainly through agents and about 85 per cent of marketing channels is agent oriented. Distance factor again plays here an important role in case of dependence on agent to market the farm produce.

Table 5: Generic constraints to the fruit and vegetable processing industry

\begin{tabular}{|c|c|c|}
\hline & Generic constraints & $\begin{array}{l}\text { Scale } \\
\text { points }\end{array}$ \\
\hline \multirow{3}{*}{$\begin{array}{l}\text { Lack of firm- } \\
\text { farm linkage }\end{array}$} & Non-availability of raw materials & 3.10 \\
\hline & Price of raw materials & 2.48 \\
\hline & Quality of raw materials & 3.25 \\
\hline \multirow{4}{*}{ Infrastructural } & $\begin{array}{l}\text { Poor transport for fruits and } \\
\text { vegetables }\end{array}$ & 3.75 \\
\hline & Lack of cold chain facilities & 4.28 \\
\hline & Frequent power cut & 4.03 \\
\hline & R\&D investment & 3.93 \\
\hline \multirow{4}{*}{ Technological } & Age old machine & 4.03 \\
\hline & Supply chain related problems & 3.48 \\
\hline & Poor quality control (for export) & 4.10 \\
\hline & Packaging problems & 4.13 \\
\hline \multirow{6}{*}{ Institutional } & Tax rates for processing industry & 2.68 \\
\hline & $\begin{array}{l}\text { Lack of public support (Subsidy/ } \\
\text { Assistance) }\end{array}$ & 2.71 \\
\hline & Product price (High cost addition) & 3.58 \\
\hline & Scarcity of labour & 3.35 \\
\hline & $\begin{array}{l}\text { Consumer's sensibility for } \\
\text { product brand }\end{array}$ & 2.95 \\
\hline & $\begin{array}{l}\text { Concentration of unorganized } \\
\text { and tiny firms }\end{array}$ & 2.35 \\
\hline
\end{tabular}

Source: Field survey by the author.
However, there hardly exists any perceptible number of food processing industries adjacent to the fruit and vegetables producing areas where the farmers could discharge their products directly. Existence of middlemen, further, creates the problem of proper price realization of their produce to the farmers. No subsidy on farm input is available to them rather they have to purchase farm inputs through black market. Lack of government monitoring or absence of government input distribution centre gives rise to black marketing on farm inputs.

In case of processing an attempt has been made to identify the major constraints of fruit and vegetable processing industry in Bengal as a whole. The results are presented in Table 5 and are based on the responses provided by the sampled firms. The results of our analysis indicate that infrastructural and technological constraints are most limiting constraints to growth and development of fruit and vegetable processing industry in Bengal.

Within infrastructure, there exists a high degree of problems in all the areas like poor transportation facilities, lack of cold chain facilities, frequent power cuts, and insufficient investments in research and development. But the growth of processing industry appears to be more constrained because of lack of cold chain facilities and power cuts. In case of technological constraints those related to age-old machinery, poor quality control for export and packaging are the major areas of concern. Poor linkage between the producer farmers and processing firms is another generic constraints faced by the industry which ultimately gives rise to the problems of non-availability of raw materials, high raw materials price to the firms due to involvement of middlemen, and failure to meet the quality standards of the produce. On an average 4 to 6 intermediaries are involved in the supply chain for fruits and vegetables in the state. This reduces the farm gate price for the products in one hand and on the other hand increases the raw material costs for the processing units.

In fact, the huge margins kept by the agents and other intermediaries are around 50 to 70 per cent of the prices paid by the processing firms and that too without any value addition to the product. To address this problem, appropriate institutional arrangements is essential. Institutional constraints relating to high tax rates, lack of government 
support, consumer's sensibility on product brand, and dominance of unorganized units remain more or less at moderate levels while high product price and labour scarcity constitute a relatively more serious problem to the industry.

Against this fact a regression model is prepared to identify the major driving forces and constraints as well of state's fruit and vegetable processing industry and to suggest policies accordingly. The finding of the model shows that infrastructure, urbanization and income growth are the major drivers for growth in fruit and vegetable processing in Bengal (Table 6).

Table 6: Regression model to identify the major determinants of fruit and vegetable processing in Bengal

\begin{tabular}{lc}
\hline Explanatory variables & Co-efficient \\
\hline \multicolumn{1}{c}{ Dependent variable (percentage level of processing) } \\
\hline Intercept & $-4.82^{*}$ \\
Relative infrastructure index (India=100) & $+0.02^{* *}$ \\
\% share of urban population & $+0.09^{* *}$ \\
Per capita annual income (,000 rupees at 2000- & $+0.85^{* * *}$ \\
01 price) & \\
Adjusted R2 value & 0.82
\end{tabular}

Level of significance-(* at $1 \%$ level; ${ }^{* *}$ at $5 \%$ level; ${ }^{* *} 10 \%$ level).

The existing infrastructure facilities in the state are found to be concentrated near big cities/ metropolitans that are far away from the producing areas, and this explains why processing units tend to concentrate in areas with better infrastructural endowments rather than where raw materials are produced. However, the overall quantity and quality of infrastructure remain far below the requirements, the future growth and expansion in fruit and vegetable processing in Bengal depends to a large extent on efforts of the state government in developing the necessary infrastructural facilities particularly in rural areas and in improving agricultural marketing in the state. Again, about 70 to 75 per cent demand for processed food comes from urban people. There seems to be a need to enhance the consumption of processed food in rural areas through the spread of electronic media and strategy to capture the rural market by the processing firms. But high prices of processed foods and low per capita income in rural areas are the restricting forces in exploiting the huge untapped potential for processed fruit and vegetable industry in the state. Therefore industry must focus on reducing the MRP of processed items.

Therefore, based on the above mentioned findings, following suggestions are made in terms of technology, infrastructure, institution and policy supports.

\section{SUGGESTIONS}

\section{Technology Related}

As regards the technological fronts the following suggestions are made to achieve the future progress of fruit and vegetable processing in Bengal.

\section{Research and development in varietal improvement}

It has been observed that fresh fruit and vegetables that are grown in India in general and in Bengal in particular are of mostly table varieties with poor shelf-life. For example the Alphanso variety of mango is very popular but is having very low pulp content. Pulp content is very high in another popular variety named Totapuri, but it is very much prone to insect attack. Similarly, potato varieties produced in Bengal are not at all suitable for making potato chips because of their uneven size and high sugar content. High pip content in commonly grown orange varieties results into bitterness in the juice and therefore is not suitable for processing. Similar problems are there for almost all the fruits and vegetables grown in the state like litchi, pineapple, tomato, etc. Therefore, there is an urgent need for varietal development of fresh fruit and vegetables with higher solid content and with more pulp percentage, considering the fact that processing requires such varieties.

\section{Promoting post harvest-handling techniques}

Huge post harvest losses in case of fruit and vegetables can be minimized by promoting proper post harvest handling techniques like controlled ripening of fruit and vegetables, cleaning properly after harvesting; storing the harvest in a right place with appropriate temperature, and waxing them for higher durability. Further modern techniques like chorine treatment, sprout treatment, trimming, etc. will help in extending their durability for longer period. 


\section{Stringent quality control measures}

Lack of quality control in production and processing restricts the exports due to pesticide content in raw fruit and vegetables. Further, non compliance with international quality standards in the line of 'Sanitary and Phyto Sanitary' (SPS) measures, 'Hazard Analysis and Critical Control Points' (HACCP), 'International Food Standards' (IFA) etc, Indian processed foods are facing serious problem in international market. Keeping the quality problem in mind, government should adopt stringent quality control measures so that Indian processed food industry can easily access the international market for their products. Of late, Government of India enacted the Food Safety and Standards Act, 2006 and established the Food Safety and Standards Authority of India (FSSAI) w.e.f. August 5, 2011 in order to ensure stringent quality in food products. Replacement of old quality standards as stipulated in the Prevention of Food Adulteration Act, 1954 with new food quality standards will pave the way for export and domestic consumption of a variety of processed fruit and vegetable items.

\section{Promote multipurpose processing technology}

The extent of capacity utilization in the fruit and vegetable processing sector in Bengal is currently found to be just below 50 per cent on an average. This implies a serious underutilization of capacity which serves as a constraint to its efficiency and profitability. One of the fundamental reasons behind this is that the bulk of the existing processing firms are engaged in single product processing. Hence, to increase the degree of capacity utilization it seems highly necessary to promote multi-product processing technology.

\section{Sophisticated packaging technology}

Packaging is an important item in agro-processing. Lack of sophisticated packaging technology and high cost of packaging materials hinder the growth of processed food. While world packaging cost is less than 5 per cent of the MRP, it is $15-20$ per cent in Bengal. The range of packaging materials available in the country is also limited. Imports of packaging materials are permitted but with high custom duty which needs a review now. There is an urgent need to strengthen research and development efforts in packaging of raw produce of fruit and vegetables along with processed products with reduced costs. Corrugated fibre board boxes may be promoted for packaging fruit and vegetables.

\section{INFRASTRUCTURE RELATED}

This study strongly points to poor infrastructure as a generic constraint to the growth and development of fruit and vegetable processing sector in the state. The major problems have been observed in areas of storage, transport and power supply. Thus, storage and transport system (cold chain) needs special attention to reduce huge post harvest losses. Specific suggestions in this regard may be:

(a) Large-scale development of multi-purpose cold storage facilities system throughout the state is needed on urgent basis. Government should come forward and encourage private entrepreneurs to establish ware houses and multipurpose cold storage facilities for fruit and vegetable items at least one in each block.

(b) Use of refrigerated vehicles both at public and private sector should be encouraged to reduce the perishability risk in transit. Developing cargo complex for perishable products in all ports and air-stations to attain highest level of preservation norms for export will be of great help.

(c) Rail and road connectivity should be improved throughout the state and conditions of road should be improved immediately to avoid post harvest losses at a large scale. Each and every village of the state should be linked with all-weather roads.

(d) Irregular power supply with frequent phenomenon of low voltage is another matter of worry to the processing sector in the state. Hence, utmost priority should be given from the government end to ensure un-interrupted power supply to the industrial sector at a reasonable price. Prior information on any kind of pre- planned power-cut should also be given to the industrial sector so that they can able to manage their production loss.

(e) There is an urgent need to develop marketing infrastructure in the state. It seems necessary to promote market intelligence and e-governance in processing industries 
in present day context of changed economic environment.

\section{INSTITUTIONAL ARRANGEMENTS}

The time has now arrived to re-think about the role of state and private sector in agricultural marketing. Quite a few acts and laws particularly the Essential Commodity Act (ECA), 1955 and Agricultural Produce and Marketing Act (APMC) need revision. Repeal of ECA would remove all controls on movement and storage of agricultural commodities across the country and would be a step towards making India one integrated market. This would also encourage the private sector (including foreign investors), co-operatives, Self Help Groups (SHGs), panchayats, etc. to develop modern storage and bulk handling facilities for different commodities. The provisions of the APMC Act have to be modified to create a lawful role for the private sector and allow the setting up of alternative marketing systems in private/corporate sector. Government's role should be of a facilitator of all infrastructure facilities, rather than having control over the management of the markets. Few states have already taken initiatives in this respect. In this background, we can think of promoting one or more of the following institutional arrangements to promote fruit and vegetable processing in Bengal.

\section{Promotion of direct marketing by farmers}

Direct marketing (retailing) by farmers was experimented through 'Apni Mandis' in Punjab and Haryana. A modified concept was introduced in Andhra Pradesh through 'Rythu Bazars' and in Tamil Nadu through 'Uzhavar Santhaigal'. Development of similar markets atleast in every block in Bengal (Kisan Bazar) is an urgent need where farmers can directly sale their produces. However, the problem with this approach lies in the lack of monitoring, supervision and implementation to eliminate middlemen.

\section{Promotion of contract farming in fruit and vegetable}

Since both the post harvest losses as well as marketing margin in fruit and vegetables are very high because of its very nature of perishability, contract farming may be of help in this matter. Available literature and evidences in several states in India (Punjab, Karnataka, Tamilnadu, Andhra Pradesh, Maharashtra, etc.), and perception of a large number of industries and producer farmers in our study area support this views. Therefore, there is a need to allow and promote contract farming in Bengal at least in fruit and vegetable cultivation with necessary safe-guards for the farmers in the event of crop failure and non-compliance of agreements by both the parties.

\section{Promotion of Spoke and Hub models (with modification)}

This model stresses on primary processing at production site to reduce post harvest loss and generate employment in rural areas; then on secondary processing near urban markets in order to facilitate distribution, marketing and quality control. In order to promote fruit and vegetable processing in Bengal, we can think of establishing primary processing units near production areas through farmers', co-operative or 'Self-Help Groups' and then allow these units to supply directly to large firms for secondary processing near urban markets through contractual arrangements. So contract farming will be held between farmers co-operative or self help groups (Primary processing units) and the processing firms (Secondary processing units) which indirectly provide safeguards to the crop growers as they are not directly engaged in contracts with processing firms. Pictorially this modified Spoke and Hub model is represented in Fig. 3.

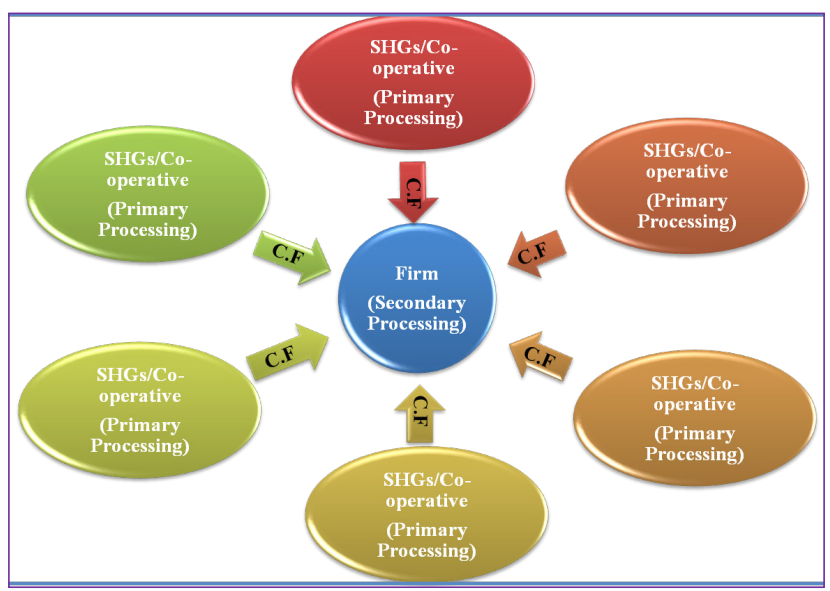

Fig. 3: Spoke and Hub model (with modification)

\section{POLICY RELATED SUGGESTIONS}

This paper suggests that a number of significant interventions are needed on the policy front to 
integrate different policy measures in a more effective and consistent chain of impact consequences. In that, the most desired and urgent changes in the existing policy structure may be suggested as follows:

(a) In order to promote export and confidence of domestic consumers it is necessary to introduce environment friendly stringent food safety and quality law. The organized sector should be brought under the compulsion of making compliance to such requirements and standards as 'Sanitary and Phyto Sanitary' (SPS), 'Hazard Analysis and Critical Control Points' (HACCP), 'Total Quality Management' (TQM), 'Good Manufacturing Practices' (GMP), 'Good Hygienic Practices' (GHP), 'CODEX', 'Food Business Order' (FBO), 'AGMARK' etc. to prepare them to face the global competition in international trade.

(b) At present many outdated laws like Food Adulteration Act, Essential Commodity Act, APMC Act are found to exist which affect the dynamic progress of food processing sector in a negative way. These ineffective laws should be abolished or amended immediately. Moreover, there is a need to bring parity among various laws.

(c) The burden of various taxes like value added tax, mandi tax, packaging tax, octroi to the food processing units is found to be rather high. This calls for a further tax reform to provide dynamic incentives to the producers by reducing the total tax burden to its minimum in the range of 0 to 10 per cent. In most of the countries where food processing is a success story, the tax burden is very low.

(d) The food processing industry is shrouded in a variety of laws spanning from the setting up of the factory to quality control of the final product. There are currently more than 20 laws and approval from 12 ministries are necessary that govern the food processing industry making the launch of a new product difficult and time consuming. It is not just the number of laws but their natures also create difficulties. Such difficult and time consuming proposition must be reduced to a more accessible one through adopting a single window approach by the government. (e) The government should come forward to invest on infrastructural facilities like refrigerated vans, assembling centre, grading and packaging houses and post harvest treatment plants etc., in joint and co-operative sectors.

(f) Government's participation is highly needed to provide financial assistance through bank for creating cold storage facilities in the state.

(g) Proper training facilities in order to groom the farmers as well as processors of fruit and vegetable items about advanced production and processing techniques is required at a large scale in the state. In this connection it may be suggested that mobile skill development and training centres should be organized to impart the required technical knowledge and expertise to the farmers' and food processors. Very recently such mobile training centres have been successfully experimented in the neighboring state of Jharkhand for defusing farm technology among the farmers' free of cost.

(h) In order to provide a safety net to the workers, the agro-processing industry should be declared as 'Seasonal Industry' for the purpose of a more objective labour act.

(i) Deregulation of 'Pickles' and 'Chutney' from the small scale industry seems to be highly important to minimize inefficiency out of sheltering.

(j) Branding of products needs to be promoted in the state, as the branded products fetch higher prices in comparison to unbranded items.

(k) For reducing excessive margins, a high degree of competition may be promoted through retail marketing. The Indian retail market is growing very fast. At present the Indian retail market is dominated by unorganized sector. Only 3 per cent of the total sale is done by the organized sector. The entry of organized sectors in retail business is bringing new technologies and more investment in marketing. It is also creating new job opportunities, but it may also displace the existing self-employed people. Fears are also being expressed that, by 
virtue of their size and power, multinational companies (MNCs) and large agri-business firms may space out small traders, processors and retailers. Thus, there is a need to examine the possible impact of entry of multinationals on the existing retailers.

The study establishes it clearly that the unexploited potentials of the fruit and vegetable processing sector in Bengal, the major problems lie with poor infrastructure, primitive production and processing technologies, poor quality control, and lack of farm-firm linkages. Hence, the urgent need is that the government should invest more on developing hardcore infrastructure in view of the fact that the private sector is not likely to come forward to invest for infrastructural development. In that the priority areas appear to be road, power, transport, and cold chain system. It may be mentioned in this context that Bengal agriculture is dominated by small and marginal producers and this scenario, given the agrarian structure, will continue to remain the same. Thus it is highly important that our research and development system must provide an efficient alternative to small producers for improving their product quality, income, and employment opportunity. In this context efficient institutional arrangements for promoting farm-firm linkages and enforcing stringent food laws seem to constitute the need of the time.

\section{REFERENCES}

CII-McKinsey \& Co. 1997. Modernizing the Indian Food Chain, Foods \& Agriculture Integrated Development Action (FAIDA), CII-McKinsey E Co., New Delhi.

GoWB. 2006. Agri Export Zones in West Bengal: A fabulous menu of investment opportunities, Department of Food Processing Industries and Horticulture, Mayukh Bhavan, Kolkata, pp.21+iii.
GoWB. 2007. District Statistical Hand Book. Bureau of Applied Economics and Statistics, GoWB.

GoWB. 2010a. Annual Report, Commerce and Industries Department, GoWB.

GoWB. 2010b. Annual Report. Department of Food Processing Industries and Horticulture, GoWB.

GoWB. 2010c. State Domestic Product and District Domestic Product of West Bengal. Bureau of Applied Economics and Statistics, GoWB.

GoWB. 2011. Sanchar, First issue, Department of Food Processing Industries and Horticulture, Mayukh Bhavan, Kolkata, pp-16.

Gulati, A., Sharma, K., Das, S. and Chhabra,V. 1994. Export Competitiveness of Selected Agricultural Commodities, National Council of Applied Economic Research, New Delhi.

Kumar, P. 1998. Food Demand Supply Projections, Indian Agricultural Research Institute, New Delhi.

MOFPI. 2011. Annual Report. Ministry of Food Processing Industries. GoI.

NHB. 2011. Horticultural Statistics, various issues. Ministry of Agriculture, GoI.

Roy, B.C. 2010. Problems and Prospects of Fruit and Vegetable Processing in India, In: K. K.Bagchi (Ed.) Promoting Horticulture in India: Challenges and Strategies, Abhijeet Publication, Delhi, pp xi+362 (ISBN 9789380031743).

Roy, B. C. and Ojha, S. 2012. Diversification of Agriculture in West Bengal: A Case for Promotion of Fruit and Vegetable Processing Industry, Paper presented in the Regional Seminar on "Diversification of Agriculture in Eastern India" to be held at Agro-Economic Research Centre, Visva Bharati during 23-25 March, 2012 in collaboration with Indian Society of Agricultural Economics, Mumbai. 